\section{Process Of Developing Materials For EFL}

\section{Classes}

\section{Pardayeva Feruza Muhammadjanovna, \\ English Language Teacher, School №26 In Angren Town, Tashkent Region, Uzbekistan}

\author{
Abdurakhimova Ra'no Pulatovna \\ English Language Teacher, School №14 In Angren Town, \\ Tashkent Region, Uzbekistan
}

\author{
G open ACCEss \\ The American Journal of \\ Social Science And \\ Education Innovations \\ JULY 2020 \\ Page No.: 270-277 \\ Volume-II Issue-VII \\ PUBLISHED: 30 JULY 2020 \\ www.usajournalshub.com/inde \\ x.php/tajssei \\ Copyright: Original content \\ from this work may be used \\ under the terms of the \\ Creative Commons Attribution \\ 4.0 licence.
}

\begin{abstract}
In this article the procedures and principles of materials development are discussed using several actual ideas. Moreover, the paper presents different types of materials which can be used in teaching English as a foreign language. It also provides the key features which should be taken into account when developing optimal and suitable materials for EFL classes. Furthermore, the article evaluates significant advantages and disadvantages of types of materials developed regarding its usage and level.
\end{abstract}

Keywords: Material development, relevancy, student learning styles, usage of grammar, $E F L, E S L$, curriculum, available sources, suitable material, practical usage, language learning.

\title{
Introduction
}

Materials development is both a field of study and a practical undertaking. As a field it studies the principles and procedures of the design, implementation and evaluation of 
language teaching materials' $[1 ; 66]$. As a practical undertaking it refers to anything which is done by writers, teachers or learners to provide sources of language input, to use those sources in ways which maximize the chance of intake and to stimulate purposeful output: in other words the supplying of information about experience of the language in ways designed to promote language learning.

Materials developers might write textbooks, tell stories, bring advertisements into the classroom, express an opinion, provide samples of language use or read a poem aloud. Whatever they do to provide input, they do so ideally in principled ways related to what they know about how languages can be effectively learned. There are many reasons for teachers to construct their own teaching materials, although every education sphere is provided with the mass of commercially produced materials. It is not easy to create new materials for every new lesson but using authentic and colorful materials can drive teacher to the successful lesson. In this case, teachers should first care about their students' interests, abilities and thoughts. Also to start learning any new language cannot be carried out without giving motivation. Every teacher puts a question "How to create/modify materials?". Here, teachers should know how to adapt existing materials easily in order to cover all students' needs. But using existing materials than creating new ones is much easier and saves time as well as effort and expenses in acquiring the English language. Existing and available materials may have to be modified including followings:

Unsuitable material level - while mastering authentic materials students may have problems because of materials' academic language or their content. As we know authentic materials are produced covering native speakers' needs and therefore non-native speakers come across difficulties in acquiring them. Before giving such materials, teacher should vary their difficult parts or adjust pupils by introducing some passages. Teachers should simplify the content or the language of the material if learners have problems with acquiring it, because it is not effective to teach with a lot of difficult and incomprehensible materials.

Too long or short - sometimes the activities teachers chose take long time and there may come out a problem concerning time. Even one activity or a small teaching material can waste time in order to explain and perform it. Sometimes teachers don't plan the time 
of the explaining teaching materials and as a result there may appear a cavity to connect new materials. Therefore materials shouldn't be too long or too short. Shorter pieces may be lengthened by activities or discussions to flesh out its usage in the classroom.

Usage of grammar - there is no need of wide use of grammar or structures if the learners are in advanced level, only thing teachers should do with grammar is just revising some structure which is connected to the theme. But not many learners can ignore the grammar lessons and they insist on adjustments on difficult topics and their structures in the way of glossaries, key word definitions or explanations before the introducing of the passage.

Exploring relevancy - using language in a relevant context to promote meaningful input and output from the learners is a key aspect of foreign language learning. If material has no obvious relevancy for the learners, it will be that much more difficult for them to approach its acquisition.

Adapting student learning styles - "Student learning styles may be an important factor in the success of teaching and may not necessarily reflect those that teachers recommend" says Jack C. Richards, noted Linguistics professional and an author of the Interchange EFL / ESL series course books. Teachers may see the ways of teaching learners considering of their knowledge. Each learner has their way of learning and they direct students to the easiest way to learn. So changing authentic materials should be taught according to the learning styles accepted by various professionals and teachers. In designing their own materials teachers can also make decisions about the most appropriate organizing principle/focus for the materials and activities, and this can be changed over the course of the program if necessary. Most course books are organized including much grammar elements and the PPP (presentation, practice, production) model of teaching. The range of possibilities of topics, notions, situations, skills direct materials developers and focus on the developing needs of learners.

Materials form an important part of the teaching and learning process, therefore teachers rely heavily on a diverse range of materials to support their teaching and students' learning process. As we know, wide - spread types of materials are from textbooks, videotapes and pictures to the Internet, but despite commercially availability of 
teaching materials, many teachers prolong to design their own materials for classroom use. Indeed, most teachers spend much time on finding, selecting, evaluating, adapting and making materials to use for their classroom. In the following there are some of the advantages and disadvantages explore why teachers want to design/adapt their own teaching materials.

\section{Advantages}

By analyzing advantages and disadvantages of using texts or course books teachers may focus to teacher-produced materials and consider that the drawbacks of course books can turn to advantages in designing teaching materials. An important advantage of teacherproduced materials is the resources available. Some teaching contexts will be rich in resources such as course books, supplementary texts, computers, audio-visual equipment and consumables such as paper, pens and so on. Other contexts may be impoverished with more than an old blackboard and a few pieces of chalk. A lack of commercial materials forces teachers to utilize their own resources and designing their own teaching materials can enable them to make best use of the resources available in their teaching context. A further aspect that is not often mentioned in literatures is the cost of commercially produced resources. For many schools, teacher-produced materials can be the best option in terms of both school and student budget. English language teaching materials should be authentic.

In language teaching literature there are many debates about the desirability of using authentic materials in language teaching classes. It is the authors' view that it is imperative for second language learners to be regularly exposed in the classroom to real, unscripted language-to passages that have not been produced specifically for language learning purposes. As Nunan points out, "texts written specifically for the classroom generally change the language in some way". [2;6] Bringing authenticity to the materials and the classroom is mainly done in terms of the texts presented to learners, written material such as newspapers and magazines.

Materials designers should also aim for authentic spoken and visual texts so as to supply learners to hear, see and read the way native speakers communicate with each other naturally. Besides, in acquiring the authentic materials learners are asked to 
perform the real - world tasks in order to comprehend and reflect the teaching authentic materials. While learners perform with them, those tasks form their particular behavior and help learners get new concepts about the language, the world outside the classroom.

A further advantage of teacher-designed materials is timeliness $[3 ; 215]$. Teachers designing their own materials can respond to local and international events with up-todate, relevant and high interest topics and tasks. Adding daily or current events/news to the materials may give new knowledge and help to form students' own views about what happening in the world.

Personalization is another advantage of teacher-designed materials. In his 1991 article, Block argues in favor of 'home-made' materials saying that they add a personal touch to teaching that students appreciate. Tapping into the interests and taking account of the learning styles of students is likely to increase engagement in learning. Also, home-made materials increase students' motivation and urge them to be joined in every lesson, especially brightly colored teaching materials take learners' attention much rather than simply constructed materials.

\section{Disadvantages}

There are a number of potential mistakes for teachers who would be materials designers. Possibly the most common criticism against teacher-made materials is about their quality. At the surface level, teacher-made materials may "seem ragged and unprofessional next to those produced by professionals." [3;212] They may contain errors, poorly constructed, lack of exactness in layout and print and lack durability. Harmer probably speaks for many when he says, "If the alternative is a collection of scruffy photocopies, give me a wellproduced course book any time." [4;51] Besides, a lack of experience and understanding about the organization may result in important elements being left out or inadequately covered. Teacher-made materials may be produced to take advantage of authentic text, but without clear criteria and some experience, teachers may make inconsistent or poor choices of texts. A further problem may be without knowing clear instructions about how to make effective use of the materials - particularly instructions designed for students. Yet another disadvantage of teacher-made materials inhibiting till these days is time. Designing own teaching materials may be time - consuming and sometimes it may lead 
not to be ready completely in order to start the lesson with well - designed materials. Hence the materials should be done not so complicated and not taking too much time to form them.

There are several key factors given that teachers need to take into account when starting the design of teaching materials for their learners. Materials should achieve impact, and impact is achieved when materials have a noticeable effect on learners, when they feel curiosity, interest and attention to the materials. If this is achieved, there is a better chance that some of the language in the materials will be taken in for processing. Materials can achieve impact through novelty (e.g. unusual topics, illustrations and activities), variety (e.g. breaking up the monotony of a unit routine with an unexpected activity; using many different text-types taken from many different types of sources; using a number of different instructor voices on a CD), attractive presentation (e.g. use of attractive colors; lots of white space; use of photographs), appealing content (e.g. topics of interest to the target learners; topics which offer the possibility of learning something new; engaging stories; universal themes; local references) and achievable challenge (e.g. tasks which challenge the learners to think). But there is a point that impact is variable.

Particular teaching materials may not have the same impact on one group of learners while another group has. In order to raise the likelihood of achieving impact, the teachers need to know as much as possible about the target learners and about how to attract these learners' attention. Also numerous choices of topics, texts and activities may assist to get the achievement of impact. Materials should help learners to feel at ease. Learning a language with anxiety or hesitation affects learners' knowledge to become more superficial. Relaxed and comfortable students apparently can learn more in shorter periods of time $[5 ; 10]$. Although it is known that pressure can stimulate some types of language learners, most researchers would agree that most language learners benefit from feeling at ease and when they feel anxious, uncomfortable they lose opportunities for language learning. Some materials developers argue that it is the responsibility of the teacher to help the learners to feel at ease and in this case the materials can provide this including exact and available information.

Materials can help learners to feel at ease in a number of ways. Learners feel more 
comfortable with written materials with lots of white space than they do with materials in which lots of different activities are crammed together on the same page; they are more at ease with texts and illustrations that they can relate to their own culture than they are with those which appear to them to be culturally alien; learners are more relaxed with materials which are obviously trying to help them to learn than they are with materials which are always testing them. Teachers can create comfortable atmosphere in the classroom by chatting to the learners casually and trying to achieve personal contact with them by revealing their own preferences, interests and opinions. Teacher's active voice, giving real life and interesting examples, showing unusual cultural samples and others make learners feel at ease during the communication with the teacher.

English language teaching materials should encourage learners to develop learning skills and strategies. Teaching any new language within the limited time is too complicated task and if it is done in the classroom. In addition to teaching valuable new language skills, it is essential that language teaching materials also teach their target learners how to learn, and they help them to take advantage of language learning opportunities outside the classroom. Hall $(6 ; 14)$ stresses that giving learners confidence in language learning will help them defeat initial difficulties during their communications. Relaxed and selfconfident learners learn faster $[5 ; 10]$. Most materials developers help learners to develop confidence through a process of simplification. They ask learners to use simple language to accomplish easy tasks such as completing substitution tables, writing simple sentences and filling in the blanks in dialogues. This approach is welcomed by many teachers and learners. But it only succeeds in diminishing the learners. They become aware that the process is being simplified for them and they are not really using their brains, as a result their success is an illusion. And this can even lead to a reduction in confidence. To this end, using well - designed materials with strategies such as rewording and using facial expressions and body language can result effectively. Elementary-level learners can often gain greater confidence from making up a story, writing a short poem or making a grammatical discovery.

\section{Conclusion}

Language teaching materials can tend to focus on one particular skill in a somewhat 
unnatural manner. To date some courses have a major focus on productive skills, and in these reading and listening become second-rate skills. But sometimes we may encounter that some materials focus on listening and speaking skills. Bell \& Gower point out that, "at the very least we listen and speak together, and read and write together" $[7 ; 125]$. Ideally, materials produced should give learners opportunities to integrate all the language skills in an authentic manner and to become competent at integrating extra-linguistic factors also. The curriculum and the context are variables that will significantly impact on decisions about teaching materials.

\section{References}

1. Dörnyei, Z., \& Ushioda, E. Teaching and researching motivation (2nd ed.). Harlow, England: Pearson Longman. 2011

2. Tomlinson, B. (ed) Materials Development in Language Teaching.

Cambridge: Cambridge University Press. 2001

3. Nunan, D. Principles for designing language teaching materials, Guidelines. 1998. 10(2), 1-24

4. Block, D. Some thoughts on DIY material design. ELT Journal, 1991, 45(3), 211-217

5. Harmer, J. Coursebooks. A human, cultural and linguistic disaster? MET, 2001, 8(3), 49-53

6. Dulay, Burt and Krashen. Edited by Brian Tomlinson. Materials Development in Language Teaching, Second Edition, Excerpt. Cambridge University Press. 1982

7. Hall, D. Materials production: Theory and practice. In A. C. Hidalgo, D. Hall, \& G. M. Jacobs (Eds.), Getting started: Materials writers on materials writing (pp. 8-14). Singapore: SEAMO Regional Language Centre. 1995 